\title{
Life Cycle Cost of Solar Biomass Hybrid Dryer Systems for Cashew Drying of Nuts in India
}

\author{
Saravanan DHANUSHKODI ${ }^{1 *}$, Vincent H WILSON ${ }^{2}$, Kumarasamy SUDHAKAR ${ }^{3}$ \\ ${ }^{1}$ PRIST University, Thanjavur, Tamilnadu 613403, India \\ ${ }^{2}$ Toc H Institute of Science and Technology, Arakkunnam, Kerala 682313, India \\ ${ }^{3}$ Energy Centre, National Institute of Technology, Bhopal 462003, Madhya Pradesh, India
}

\begin{abstract}
Cashew nut farming in India is mostly carried out in small and marginal holdings. Energy consumption in the small scale cashew nut processing industry is very high and is mainly due to the high energy consumption of the drying process. The drying operation provides a lot of scope for energy saving and substitutions of other renewable energy sources. Renewable energy-based drying systems with loading capacity of $40 \mathrm{~kg}$ were proposed for application in small scale cashew nut processing industries. The main objective of this work is to perform economic feasibility of substituting solar, biomass and hybrid dryer in place of conventional steam drying for cashew drying. Four economic indicators were used to assess the feasibility of three renewable based drying technologies. The payback time was 1.58 yr. for solar, 1.32 for biomass and 1.99 for the hybrid drying system, whereas as the cost-benefit estimates were 5.23 for solar, 4.15 for biomass and 3.32 for the hybrid system. It was found that it is of paramount importance to develop solar biomass hybrid dryer for small scale processing industries.
\end{abstract}

Keywords - Benefit cost ratio; conventional dryer; energy saving; pay back

\section{INTRODUCTION}

India is one of the largest producers and processors of cashews in the world [1]. In 2013-14, India exported 113,620 metric tonnes of cashews which generated US\$ 825.89 million in revenue [2]. Cultivation of cashew nuts promotes employment, and contributes to revenue through foreign exchange. In India, more than 70 percent of cashew area is under small and marginal farmers.

Cashew nut processing in India depends on raw materials, locations, type of technology and the availability of energy supply. The processing steps include drying of raw nuts, steaming the raw nuts, cooling, cutting to separate shell from kernel, drying the kernel, peeling, grading and packing. In cashew processing, much of the energy and time is consumed during the drying, steaming and kernel drying. The energy consumption of cashew nut processing to produce same quantity of similar products revealed wide variation in energy intensity, ranging from 4.43 to $8.66 \mathrm{~kg}$ of fuel wood per kilogram of kernel [3].

\subsection{Literature Review}

Sengar and Kothari carried out economic evaluation of greenhouse for cultivation of rose nursery. The total construction cost of a $80 \mathrm{~m}^{2}$ arch shape greenhouse was Rs 100000/-. Suitability of the economics of greenhouse, four economic indicators such as net present worth, internal rate of return, benefit cost ratio and payback period were calculated for rose nursery.

\footnotetext{
* Corresponding author.

E-mail address: dhanushkodi.vs@gmail.com
} 
NPW of investment made on greenhouse, the internal rate of return, the benefit cost ratio, when rose nursery grown inside the greenhouse were Rs 453221/-, $53 \%$, 4.5, respectively [5].

Barnwel and Tiwari analyzed the cost of a hybrid photovoltaic greenhouse dryer. A hybrid $\mathrm{PV} / \mathrm{T}$ integrated greenhouse dryer has been used to dry grapes under forced mode of operation. The system payback period is about 1.25 years with initial investment of Rs 27,400. The cost of drying of the grapes is Rs 4.52 per kg [6].

Debbarma et al designed and developed a low cost bamboo solar dryer at MANIT Bhopal, India to test its performance for crop drying. The dryer is a tent-type designed for multi-crop solar drying. The economic cost of bamboo dryer is around Rs 400/- which is very much affordable for the poor farmers. The payback period of the solar dryer could be recovered within one to two months [7].

Ahmad et al performed a techno-economic study of solar drying system in Malaysia. The solar dryer is designed for drying agricultural and marine products such as seaweed. The cost benefit analysis is performed assuming prevailing market prices of fresh seaweed (RM $0.2 / \mathrm{kg}$ ), dried products (RM 5/kg), salary for the workers (RM 9000/year), electricity costs (RM 600/year), maintenance and insurance cost (RM 641/year), and annual operating cost of RM 15421. The results of economic analysis indicated that the double pass solar collector is best suited for drying marine products as its payback period is as low as 2.33 years [8]

Atul et al conducted a study for the estimation of energy consumption in eight unit operation of small scale cashew nut processing in India. Solar energy, electricity and fuel are the major source of energy consumed for cashew nut processing. Finally, the total energy consumption was estimated at 5321.43, 5540.14 and 6061.34 MJ for 60,30 and $15 \mathrm{~kg}$ batch capacity industries [9].

Sachidanada et al analyzed the performance of biomass fired drier for copra drying. The results indicated that biomass fired took 22 hours to reduce initial moisture content from $57.4 \%$ $(\mathrm{Wb})$ to $6.8 \%(\mathrm{~Wb})$. The cost benefit ratio is calculated to be 1.4 and 1.19 for two drier tested for quality copra production [10].

Bala and Morshed analyzed and investigated the performance of solar tunnel dryer for drying mushrooms. The temperature in drying chamber varied from 37 to $66.5{ }^{\circ} \mathrm{C}$. The payback period of the dryer is 3.8 years [11].

Sujata et al analyzed the performance of hybrid photovoltaic thermal integrated solar dryer. The experimental study has been conducted under no load and load condition. The dryer is able to dry $90 \mathrm{~kg}$ of maize grain from the initial moisture content of 33.3 to $20 \%$. Finally, it was concluded that the PV based solar dryer is a self- sustained solar dryer with the total energy payback period of 5.6 years [12]. The existing literature survey clearly indicated that so far no work has been carried out on solar biomass hybrid drying of cashew nut [13]-[18]. Thus there is a wide gap in this area of research and therefore this study is intended to fulfil the gap on economic life cycle analysis of renewable hybrid drying system for cashew processing.

\subsection{Objective of the Study}

The economic analysis is more important for processing industries as well as the end users to find out the cost of drying. The study was conducted using the standard economic tool with the following objectives:

- To estimate the energy cost associated with conventional small-scale cashew processing industries.

- To individually compare the economic feasibility of solar-biomass hybrid in terms of payback period, rate of return, discounted cash flow and $\mathrm{B} / \mathrm{C}$ ratio.

- To study the economic feasibility of solar, biomass and hybrid system for cashew drying. 


\section{Methodology}

Data collection: The performance study of solar biomass hybrid dryer for cashew drying has been carried out by the authors [3], [4]. The cost of material and labour charges has been used to arrive at the initial cost of solar biomass and hybrid dryer. Conventional steam drying cost was obtained from the local cashew nut processing industries in Cuddalore district, India. Several indicators are available to study the economic viability of renewable energy based drying technologies which are classified and shown in Fig. 1.

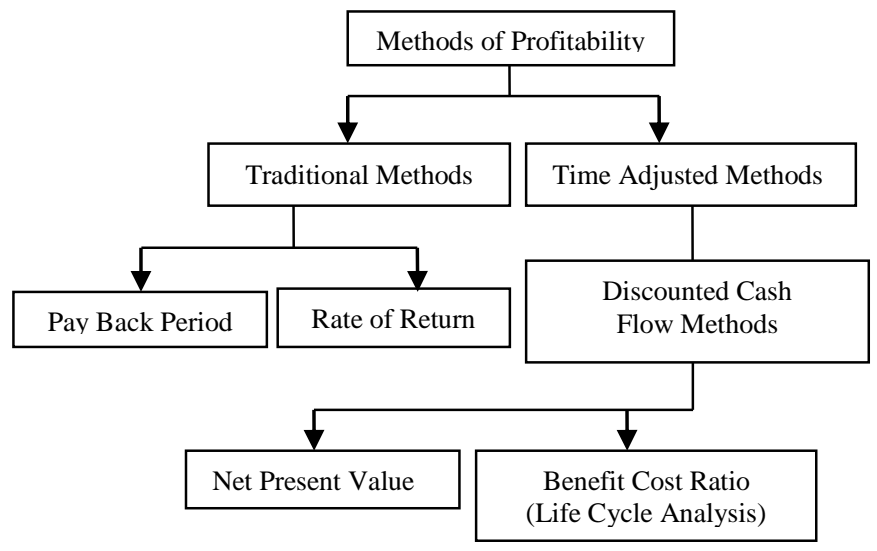

Fig. 1. Classification of profitability methods.

\section{1. $\quad$ Simple Pay Back Period}

The simple payback period is calculated by dividing the initial investment by the annual cashflows. The formula is

$$
\text { Payback Period }=\frac{\text { Initial investment }}{\text { Annual cash benefit }}
$$

The payback method measures the time period between investment and its recovery. The returns are therefore referred to as cash benefits of revenues in excess of expenditure.

\subsection{Accounting Method of Rate of Return}

According to this method, the profitability is measured on the basis of accounting information derived from the financial statement. It is also known as Accounting Rate of return Method (ARR). The accounting rate of return (ARR) is calculated by dividing the average income after taxes by the average investment or average book value after depreciation.

$$
A R R=\frac{A v g \text { Net Income after Taxes }}{\text { Avg Investment over the life of the project }}
$$

\subsection{Discounted Cash Flow Method}

The discounted cash flow technique (DCF) recognizes the changing value of money and it takes into account the fact that the same amount of money received today is more valuable than the one received after a year and so on. For projects stretching over several years, one should take into account the cash-flows expected from the project over future years and discounted 
them back to the present in order to determine the "Net Present Worth" of the investment. The formula expression is used for discounted cash flow

$$
F=P\left(\frac{(1+i)}{100}\right)^{n}
$$

\subsection{Net Present Value}

This method under DCF attempts to compare the present value of the future benefits with the present value of the investment. An important advantage of this method is that it allows comparison of the projects having different service lives, even if the life span of the project differs. The relation for finding out the total present value of all cash inflows generated from an investment is as follows:

$$
N P V=\sum_{t=1}^{n} \frac{R_{t}+S}{(1+i)^{t}}
$$

\subsection{Revenue - Dominated Cash Flow Diagram}

A generalized revenue - dominated flow diagram to demonstrate the present worth method of comparison is presented in Fig. 2.

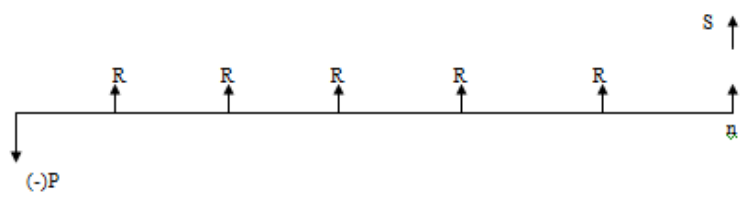

Fig. 2. Revenue - Dominated Cash Flow Diagram.

This Figure represents an initial investment and $R_{j}$ the net revenue at the end of $j^{\text {th }}$ year. The interest rate is $i$, compounded annually. $S$ is the average value at the end of the $n^{\text {th }}$ year. To find the present worth of the above cash flow diagram for a given interest rate, the formula is

$$
P W_{(i)}=-P+R_{1} \cdot \frac{1}{(1+i)^{1}}+R_{2} \cdot \frac{1}{(1+i)^{2}}+\cdots+R_{j} \cdot \frac{1}{(1+i)^{j}}+R_{n} \cdot \frac{1}{(1+i)^{n}}+S \cdot \frac{1}{(1+i)^{n}}
$$

In this formula, the expenditure is assigned a negative sign and revenues are assigned a positive sign.

\subsection{Benefit/Cost Ratio Analysis:}

Cost-benefit analysis is a systematic process for calculating and comparing benefits and costs of a project. It has two purposes:

1. To determine if it is a sound investment/decision (justification/feasibility).

2. To provide a basis for comparing projects. It involves comparing the total expected cost of each option against the total expected benefits, to see whether the benefits outweigh the costs, and by how much.

\subsection{Life Cycle Cost Analysis:}

Life Cycle Cost analysis is the systematic, analytical process of evaluating alternative courses of action early on in a project, with the objective of choosing the best alternative to employ scarce resources. It is: 
Annualized uniform cost, unacost $(R)$, is defined as the product of the net present value of the system and capital recovery factor $(C R F)$.

Annualized uniform cost/unacost $(R)=P_{N P V} \cdot C R F$

$$
R=\frac{P_{N P V} \cdot i(1+i)^{n}}{(1+i)^{n}-1}
$$

Annualized salvage value $\left(\mathrm{R}^{\prime}\right)$

$$
R^{\prime}=\frac{S}{(1+i)^{n}-1}
$$

Annualized Cost of Dried cashew kernel $(\mathrm{Rs})=\mathrm{R}-\mathrm{R}^{\prime}$. Cost of drying is $\mathrm{Cg}(\mathrm{Rs} / \mathrm{kg})$ :

$$
C g=(R / \text { dried product per year })
$$

Total Benefits

$$
B=C F-(R-R)
$$

\subsection{Assumptions}

The following assumptions were made to assess the economic feasibility of solar biomass hybrid dryer for cashew drying.

1. The useful life of the solar dryer, biomass dryer and hybrid dryer solar are taken as 20,10 and 15 years, respectively.

2. Dryer processing capacity is $40 \mathrm{~kg} / \mathrm{batch} /$ day.

3. The discount rate is 8 percent.

4. The dryer can be operated 200 days in a year.

5. The annual maintenance cost of the solar dryer, biomass dryer and hybrid dryer solar are taken as $1 \%, 2 \%$ and $3 \%$, respectively.

The economic indicators like payback period, cost-benefit and life cycle cost were used to perform the economic analysis of solar biomass hybrid dryer.

\section{RESULTS AND DiSCUSSION}

\subsection{Cost Analysis of Cashew Kernel Drying by Conventional System (Steam Drying)}

TABLE 1. ENERGY COST OF CONVENTIONAL DRYING

\begin{tabular}{lll}
\hline S. No. & Factor & Existing Conventional System \\
\hline 1 & Dryer capacity $(\mathrm{kg})$ & $180 \mathrm{~kg}$ \\
2 & Energy / batch $(\mathrm{MJ})$ & $575.64 \mathrm{MJ}$ \\
3 & Energy/day/batch $(\mathrm{kWh})$ & $159.9 \mathrm{kWh}$ \\
4 & Energy per kg (kWh/kg) & $0.888 \mathrm{kWh}$ \\
5 & Energy consumption for 40 kg & $35.52 \mathrm{kWh}$ \\
6 & Annual Total Energy consumption @ 200 days $(\mathrm{kWh})$ & $7104 \mathrm{kWh}$ \\
7 & Annual Energy Cost (Rs) @ Rs 5.6 per unit & $\mathrm{Rs} \mathrm{39787}$ \\
8 & Specific cost (Rs/kg ) & $\mathrm{Rs} 4.97 / \mathrm{kg}$ \\
\hline
\end{tabular}

The total energy consumption and energy cost associated with drying of $40 \mathrm{~kg}$ of cashew kernel can be observed in Table 1 . 
The energy consumption was $7104 \mathrm{kWh}$ and it can be noticed that the specific cost of drying per $\mathrm{kg}$ of cashew kernel is around $\mathrm{Rs} 5 / \mathrm{kg}$. The total amount of electrical energy used in the conventional dryer can be reduced substantially by adapting renewable energy based dryer. The energy consumption required to achieve the moisture reduction from $10 \%$ to $5 \%$ can be achieved using renewable energy based drying systems.

\subsection{Analysis of Initial Cost of Renewable Energy Based Dryer}

The economic feasibility of the hybrid dryer for drying of cashews was calculated by considering the initial investment of the dryer, repair and maintenance cost, cost of raw material. The cost calculations of different raw materials used for fabrication of the system are summarized in Table 2.

TABLE 2. INITIAL COST OF COMPONENTS OF RENEWABLE ENERGY BASED DRYER

\begin{tabular}{|c|c|c|c|c|}
\hline Item & Specification & Quantity & Rate (Rs) & Total (Rs) \\
\hline \multicolumn{5}{|c|}{ Solar Air collector } \\
\hline Glazing & $4 \mathrm{~mm}$ thick $\left(21.12 \mathrm{ft}^{2}\right)$ & 2 glass & 90/sq. feet & 3802.00 \\
\hline Aluminium L-Angle & $3 / 4 \times 3 / 4$ inch $\times 2 \mathrm{~mm}$ & 5 length & 270/length & 1350 \\
\hline GI Sheet & $8^{\prime} \times 4^{\prime} \times 1.6 \mathrm{~mm}$ & 3 sheet & 2550/sheet & 7650 \\
\hline Aluminium absorber plate & $8^{\prime} \times 4^{\prime} \times 2 \mathrm{~mm}$ & 1 sheet & 5880 & 5880 \\
\hline Step Angle & $1 / 2 “$ & 5 length & 250/length & 1250 \\
\hline Rivet & $1^{\prime \prime}$ & 200 & 1/unit & 200 \\
\hline Glass Wool Insulation & - & $10 \mathrm{Kg}$ & $40 / \mathrm{kg}$ & 400 \\
\hline Labour cost & & & & 3500 \\
\hline & Total & & & 24032.00 \\
\hline \multicolumn{5}{|c|}{ Drying Chamber } \\
\hline GI Sheet & $8^{\prime} \times 4^{\prime} \times 1.6 \mathrm{~mm}$ & 4 sheet & 2550/sheet & 10200 \\
\hline Aluminium L-Angle & $3 / 4 \times 3 / 4$ inch $\times 2 \mathrm{~mm}$ & 5 length & 270/length & 1350 \\
\hline Perforated aluminium sheet & $8^{\prime} \times 4^{\prime} \times 1.5 \mathrm{~mm}$ & 2 sheet & 3350/sheet & 6700 \\
\hline Square Pipe & $1 / 4^{\prime} \times 1 / 4^{\prime} \times 1.6 \mathrm{~mm}$ & 5 length & 500/length & 2500 \\
\hline Glass Wool Insulation & - & $10 \mathrm{~kg}$ & $40 / \mathrm{kg}$ & 400 \\
\hline Rivet & $1 “$ & 200 & 1/unit & 200 \\
\hline \multirow[t]{2}{*}{ Labour cost } & & & & 3000 \\
\hline & Total & & & 24350.00 \\
\hline \multicolumn{5}{|c|}{ Blower } \\
\hline Blower & $\begin{array}{l}0.37 \mathrm{~kW}, 0-2800 \mathrm{rpm}, 440 \\
\mathrm{~V}(\mathrm{AC})\end{array}$ & 1 & 10000 & 10000 \\
\hline Connecting Pipe & 3"MS pipe & 1 length & 2500/length & 2500 \\
\hline \multirow[t]{2}{*}{ Connecting Pipe } & 1.5" MS Pipe & 1 length & 850/length & 850 \\
\hline & Total & & & 13350 \\
\hline \multicolumn{5}{|l|}{ Biomass heater } \\
\hline GI Sheet & $8^{\prime} \times 4^{\prime} \times 1.6 \mathrm{~mm}$ & 1 sheet & 2550/sheet & 2550 \\
\hline MS Sheet & $6 \mathrm{~mm}(1.25 \mathrm{~m} \times 2.5 \mathrm{~m})$ & 1 sheet & 4100/sheet & 4100 \\
\hline Glass Wool Insulation & - & $8 \mathrm{~kg}$ & $40 / \mathrm{kg}$ & 320 \\
\hline Chimney Pipe & $6 " \times 1 \mathrm{~m}$ & $1 \mathrm{~m}$ & $1320 / \mathrm{m}$ & 1320 \\
\hline
\end{tabular}




\begin{tabular}{lllll} 
Stand & 20" dia x $10 \mathrm{~mm}$ & 1 piece & 300 & 300 \\
Stand Pipe & $1 \frac{1}{2}$ “" 1 1" & 3 pipe & $200 /$ pipe & 600 \\
Rivet & 1 “ & 50 & $1 /$ unit & 50 \\
Labour cost & & & 2000 \\
& Total & & $\mathbf{1 1 2 4 0}$ \\
\hline
\end{tabular}

TABLE 3. INITIAL COST OF RENEWABLE ENERGy BASED DRYERS

\begin{tabular}{clccc}
\hline No. & Component details & Solar dryer & Biomass dryer & Hybrid dryer \\
\hline 1 & Solar air collector & + & - & + \\
2 & Drying chamber & + & + & + \\
3 & Blower & + & + & + \\
4 & Biomass Heater & - & + & + \\
& Total cost & & & \\
+Applicable & & & \\
-Not Applicable &
\end{tabular}

The initial investment for the three cases of dryer with solar, biomass and hybrid dryer are Rs Rs 61, 732, Rs 48, 940 and Rs 72, 972, respectively. It is arrived at by adding the materials cost of the components of the dryer (Table 3 ).

\subsection{Economic Analysis of Solar Biomass Hybrid (Renewable Energy Based Dryer for Cashew Processing)}

Table 4 comprises the data about the Factors like the Initial Investment, Salvage value, Annual Savings from conventional energy cost, operating and maintenance cost, expected economic life of asset, time value of money and annual cash benefit for all the three types of renewable energy based dryers.

TABLE 4. INITIAL INVESTMENT AND ANNUAL CASH Flow DATA

\begin{tabular}{|c|c|c|c|c|}
\hline No. & Factor & Solar dryer & Biomass dryer & Hybrid dryer \\
\hline 1 & Initial Investment $(\mathrm{P})$ in Rupees & 61732 & 48940 & 72972 \\
\hline 2 & $\begin{array}{l}\text { Salvage Value (S) (@10 \% of P) in } \\
\text { Rupees }\end{array}$ & 6173 & 4894 & 7297 \\
\hline 3 & $\begin{array}{l}\text { Annual Savings (Conventional Energy } \\
\text { Cost) in Rupees }\end{array}$ & 39787 & 39787 & 39787 \\
\hline 4 & $\begin{array}{l}\text { Annual Operating Cost (Annual Fuel } \\
\text { Consumption and Cost) in Rupees }\end{array}$ & 0 & $\begin{array}{l}\text { For } 8 \text { hours operation: } \\
\begin{aligned} 4 \mathrm{~kg} / \mathrm{batch} / \mathrm{day} \\
\text { Cost }=4 \cdot 200 \cdot \operatorname{Rs} 2 \\
=\operatorname{Rs} 1600\end{aligned}\end{array}$ & $\begin{array}{l}\text { For } 8 \text { hours operation: } \\
\begin{aligned} 2.5 \mathrm{~kg} / \mathrm{batch} / \text { day } \\
\text { Cost }=2.5 \cdot 200 \cdot \operatorname{Rs} 2 \\
=\operatorname{Rs} 1000\end{aligned}\end{array}$ \\
\hline 5 & Annual Cash Flow (3)-(4) & 39787 & 38187 & 38787 \\
\hline 6 & Maintenance Cost & @ $1 \%$ of $\mathrm{P}=617$ & @ $2 \%$ of $\mathrm{P}=980$ & @ $3 \%$ of $P=2190$ \\
\hline 7 & Total Cost (4)+(6) & 617 & 2580 & 3190 \\
\hline 8 & Expected Economic Life & 20 years & 10 years & 15 years \\
\hline 9 & $\begin{array}{l}\text { Time value of money (Annual Interest } \\
\text { Rate in \%) }\end{array}$ & $8 \%$ & $8 \%$ & $8 \%$ \\
\hline 10 & Annual Cash Benefit (3)-(7) & 39170 & 37207 & 36597 \\
\hline
\end{tabular}




\subsection{Economic Analysis Using Simple Payback Period Method}

TABLE 5. SIMPLE PAYBACK PERIOD

\begin{tabular}{|c|c|c|c|c|}
\hline No. & Factor & Solar & Biomass & Hybrid \\
\hline 1 & Initial Investment $(\mathrm{P})$ & 61732 & 48940 & 72972 \\
\hline 2 & Annual Cash Benefit & 39170 & 37207 & 36597 \\
\hline 3 & $\begin{array}{l}\text { Pay-Back Period in Years } \\
(1) /(2)\end{array}$ & 1.58 & 1.32 & 1.99 \\
\hline
\end{tabular}

Based on the estimated Initial and annual operating costs of the drying system for drying of cashew kernel (Table 5), the payback period of the solar, biomass and hybrid drying system for this product is estimated and this is found to vary between 1.3 to 2 years. The payback period of the biomass dryer is even less (1.34 years) than solar and hybrid dryers. The amount invested in a hybrid dryer can be recovered within 2 years. Both of these systems solar and biomass dryer have almost the same payback period, but a considerable increase in initial cost and number of components made the hybrid system payback period higher than the other two systems.

TABLE 6. ACCOUNTING RATE OF RETURN

\begin{tabular}{cllll}
\hline No. & Factor & Solar & Biomass & Hybrid \\
\hline 1 & Annual Cash Benefit & 39170 & 37207 & 36597 \\
2 & Initial Investment (P) & 61732 & 48940 & 72972 \\
3 & Salvage Value (S) & 6173 & 4894 & 7297 \\
4 & Net Investment (2)-(3) & 55559 & 44046 & 65675 \\
5 & Expected Life of the Project & 20 years & 10 years & 15 years \\
6 & Average Net Investment (4)/(5) & 2778 & 4410 & 4378 \\
7 & Average Net Income (1)-(6) & 36392 & 32797 & 32219 \\
8 & Accounting Rate of Return & $65.5 \%$ & $74.5 \%$ & $49.1 \%$ \\
\hline
\end{tabular}

TABLE 7. Net PRESENT VaLUe (NPV)

\begin{tabular}{|c|c|c|c|c|c|c|c|c|c|c|c|c|c|c|c|c|c|c|c|c|}
\hline $\mathbf{N}$ & 1 & 2 & 3 & 4 & 5 & 6 & 7 & 8 & 9 & 10 & 11 & 12 & 13 & 14 & 15 & 16 & 17 & 18 & 19 & 20 \\
\hline $\mathbf{P} / \mathbf{F}$ & ふૂ & $\begin{array}{l}\infty \\
\hat{n} \\
\infty \\
0 \\
0\end{array}$ & $\frac{\hat{\sigma}}{\hat{0}}$ & $\stackrel{n}{\tilde{n}}$ & $\begin{array}{l}\hat{2} \\
\dot{0} \\
0 \\
0\end{array}$ & $\begin{array}{l}\text { Oे } \\
\text { ర్ } \\
0\end{array}$ & $\begin{array}{l}+ \\
\infty \\
\infty \\
n \\
0\end{array}$ & 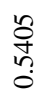 & $\tilde{0}$ & \begin{tabular}{l}
30 \\
\multirow{0}{0}{}
\end{tabular} & $\begin{array}{l}\text { ন্ } \\
\stackrel{\text { İ }}{0}\end{array}$ & 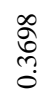 & 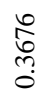 & 京 & $\frac{n}{n}$ & $\frac{n}{2}$ & 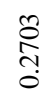 & กิ & $\frac{n}{\tilde{n}}$ & 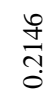 \\
\hline
\end{tabular}

\subsection{Economic Analysis Using Accounting Rate of Return Method:}

From Table 6, it can be inferred that, out of these three renewable energy based dryers, the biomass dryer gives the highest Rate of Return (75\%) when compared to the other two dryers. The hybrid dryer gives the lowest return, nearly $50 \%$ whereas solar dryer gives $65 \%$ rate of return

From the above Table 7 ,

$\sum\left(1 / 1.08^{20}\right)=9.8068$ (for 20 years $)$

$\sum\left(1 / 1.08^{10}\right)=6.7177$ (for 10 years)

$\sum\left(1 / 1.08^{15}\right)=8.5489$ (for 15 years)

For Salvage value: 
$\left(1 / 1.08^{20}\right)=0.2146($ for 20 years $)$

$\left(1 / 1.08^{10}\right)=0.4632$ (for 10 years $)$

$\left(1 / 1.08^{15}\right)=0.3152$ (for 15 years)

Present Value of the Future Benefits, Solar Dryer:

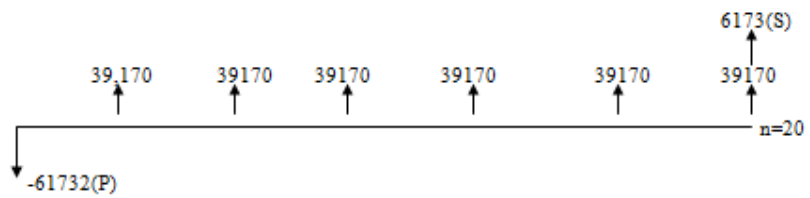

Net worth $=-61732+39170 \cdot 9.8068+6173 \cdot 0.2146=$ Rs 3,23,725

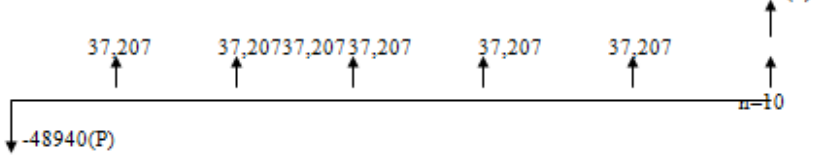

Net worth $=-48940+37207 \cdot 6.7177+4894 \cdot 0.4632=$ Rs 2,03,339

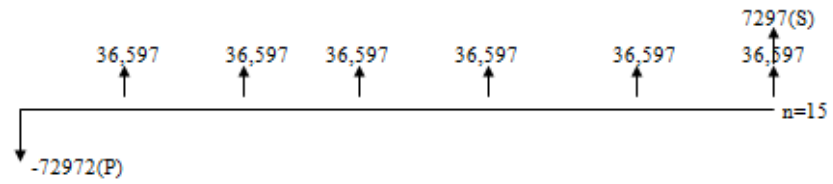

Net worth $=-72972+36597 \cdot 8.5489+7297 \cdot 0.3152=$ Rs $2,42,192$

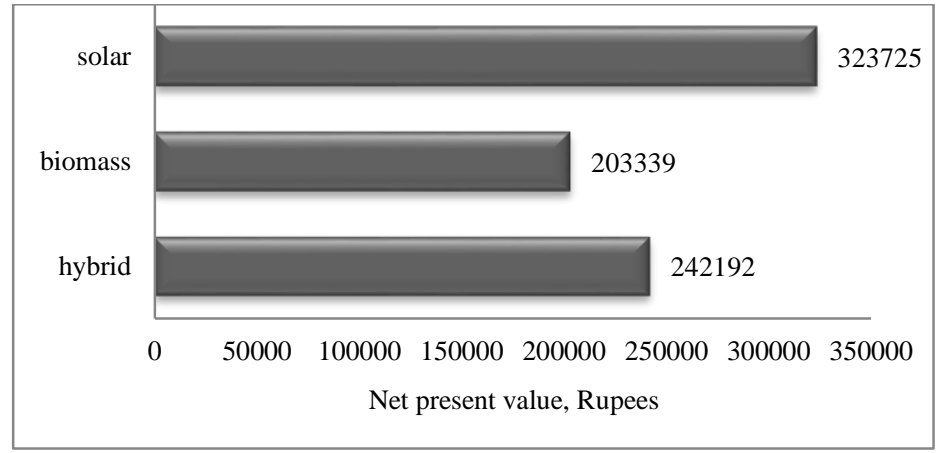

Fig. 3. Project benefit using net present value.

From Figure 3 it can be inferred that the solar dryer can be considered as the best choice on the basis of highest future worth (Rs 323725) followed by hybrid dryer (Rs 242192) and biomass dryer (Rs 203339). 


\subsection{Benefit-Cost Ratio}

TABLE 8. BENEFIT-COST RATIO

\begin{tabular}{|c|c|c|c|c|}
\hline No. & Factor & Solar Dryer & Biomass Dryer & Hybrid Dryer \\
\hline 1 & Initial Investment $(\mathrm{P})$ in Rupees & 61732 & 48940 & 72972 \\
\hline 2 & Salvage Value (S) (@10\% of P) in Rupees & 6173 & 4894 & 7297 \\
\hline 3 & $\begin{array}{l}\text { Annual Savings (Conventional Energy Cost) in } \\
\text { Rupees }\end{array}$ & 39787 & 39787 & 39787 \\
\hline 4 & Annual Operating Cost & 0 & 1600 & 1000 \\
\hline 5 & Annual Cash Flow (3)-(4) & 39787 & 38187 & 38787 \\
\hline 6 & Maintenance Cost & $\begin{array}{l}@ 1 \% \text { of } \mathrm{P}= \\
617\end{array}$ & $\begin{array}{l}\text { @ } 2 \% \text { of } \mathrm{P}= \\
980\end{array}$ & $\begin{array}{l}\text { @ } 3 \% \text { of } \mathrm{P}= \\
2190\end{array}$ \\
\hline 7 & Total Cost (4)+(6) & 617 & 2580 & 3190 \\
\hline 8 & Expected Economic Life & 20 years & 10 years & 15 years \\
\hline 9 & Time value of money (Annual Interest Rate in \%) & $8 \%$ & $8 \%$ & $8 \%$ \\
\hline 10 & Annual Cash Benefit (3)-(7) & 39170 & 37207 & 36597 \\
\hline 11 & Capital Recovery Factor $=\frac{i(1+i)^{n}}{(1+i)^{n}-1}$ & 0.102 & 0.149 & 0.117 \\
\hline 12 & $\begin{array}{l}\text { Annualized Uniform cost } \\
R=\frac{P_{N P V} i(1+i)^{n}}{(1+i)^{n}-1}\end{array}$ & $\begin{array}{l}\text { (Rs 61732·0.102) } \\
\text { Rs.6289 }\end{array}$ & $\begin{array}{l}\text { (Rs } \\
48940 \cdot 0.149) \\
\text { Rs } 7293\end{array}$ & $\begin{array}{l}\text { (Rs 72972·0.117) } \\
\text { Rs } 8526\end{array}$ \\
\hline 13 & $R^{\prime}=\frac{S}{(1+i)^{n}-1}$ & Rs 134.86 & Rs 338 & Rs 269 \\
\hline 14 & Annualized Cost of Drier $=\mathrm{R}-\dot{\mathrm{R}}$ & Rs 6154 & Rs 6955 & Rs 8257 \\
\hline 15 & $\begin{array}{l}\text { Cost of Drying } \\
\mathrm{C}=(\mathrm{R} / \text { dried product per year })\end{array}$ & $\begin{array}{l}(6289 / 8000) \\
\text { Rs } 0.786\end{array}$ & $\begin{array}{l}(7293 / 8000) \\
\text { Rs } 0.912\end{array}$ & $\begin{array}{l}(8526 / 8000) \\
1.066\end{array}$ \\
\hline 16 & $\begin{array}{l}\text { Total Benefits } \\
\mathrm{B}=\mathrm{CF}-(\mathrm{R}-\dot{\mathrm{R}})\end{array}$ & $\begin{array}{l}\text { (Rs 39170-6154) } \\
\text { Rs 33,016 }\end{array}$ & $\begin{array}{l}\text { (Rs 37207- } \\
6955 \text { ) } \\
\text { Rs 30,252 }\end{array}$ & $\begin{array}{l}\text { (Rs 36597-8257) } \\
\text { Rs 28,340 }\end{array}$ \\
\hline 17 & Benefit-Cost Ratio $(16 \div 12)=B / R$ & 5.23 & 4.15 & 3.32 \\
\hline
\end{tabular}

Costs of the processing of cashew kernels in the different renewable energy based dryers are shown in Table 8 . It was found that cost of drying is as low as Rs $1 / \mathrm{kg}$ in all the three systems. The cost-benefit ratio was also as high as 5 which shows the potential of using solar dryers in place of conventional dryers. The $\mathrm{B} / \mathrm{C}$ ratio of solar dryer was highest among all the dryers because of lower operating cost and nil fuel cost. The next system worth considered is biomass dryer with $\mathrm{B} / \mathrm{C}$ ratio 4.15 followed by Hybrid dryer. The slight reduction in $\mathrm{B} / \mathrm{C}$ ratio is due to: higher initial cost, fuel cost and operating cost of biomass and hybrid dryers. Solar, biomass and hybrid are all more economically viable than conventional drying system in terms of environmental benefits associated with adoption of this technology.

\section{CONClusion}

Renewable energy-based drying systems with loading capacity of 40/kg were proposed for application in small scale cashew nut processing industries. A techno-economic analysis of solar dryer for drying cashew kernels was carried out and compared with biomass dryers and hybrid dryers. The following conclusions could be drawn from the study: 
- The cost of drying of cashew kernel is lowest for solar dryer with initial investment of Rs 61732 as Rs $0.8 / \mathrm{kg}$.

- The estimated payback period of the hybrid dryer is about 1.99 years. The initial investment of biomass dryer (Rs 48,940) gives the lowest payback period of about 1.32 years which is much less than the expected life of the dryer.

- Biomass dryer gives the highest Rate of Return (75\%) whereas the hybrid dryer gives the lowest Return nearly $50 \%$.

- Solar dryer is the best option based on the cash discounted future worth of Rs 3,23,725 when compared to the other two types of dryers.

- Benefit cost ratio was also highest for solar dryer which was found to be 5.23.

- The developed system was found to be economically suitable for processing of $40 \mathrm{~kg}$ /batch of cashew kernel.

- Due to its economic effectiveness, this type of dryer can play a vital role in bringing sustainable energy to small scale cashew farmers in the rural communities of India.

\section{REFERENCES}

[1] Senthil A., Mahesh M. P. Analysis of Cashew nut production in India. Asia pacific Journal of Marketing and Management review 2013:2(3):106-110.

[2] Cashew Export Promotion Council of India, India Brand Equity Foundation, August 2015 [Online]. Available: www.ibef.org

[3] Dhanushkodi S., Wilson V. H., Sudhakar K. Design and thermal performance of the solar biomass hybrid dryer for cashew drying. Facta Universitatis Series: Mechanical Engineering 2014:12(3):277-288.

[4] Dhanushkodi S., Wilson V. H., Sudhakar K. Thermal Performance evaluation of Indirect forced cabinet solar dryer for cashew drying. American-Eurasian Journal of Agricultural and Environmental Science 2014:14(11):12481254. doi:10.5829/idosi.aejaes.2014.14.11.21871

[5] Sengar S. H., Kothari S. Economic evaluation of greenhouse for cultivation of rose nursery. African Journal of Agricultural Research 2008:3(6):435-439.

[6] Barnwel P., Tiwari G. N. Life Cycle Cost Analysis of a Hybrid Photovoltaic/Thermal Greenhouse Dryer. Journal of Open Environmental Sciences 2008:2:39-46.

[7] Debbarma M., Rawat P., Sudhakar K. Thermal performance of low cost solar bamboo dryer. International Journal of Chem Tech Research 2013:5:1041-1045.

[8] Ahmad F., Mohd Y., Muhamman Y., Azamia H., Sopian A. Techno-Economic Analysis of Solar Drying System for Seaweed in Malaysia. In: The Recent Researchers in Energy, Environment and Landscape Architecture.

[9] Atul M., Sudhir J., Ashok P. Quantification of energy consumption for cashew nut (Anacardiumoccidentale L.) processing operations. International Journal of Sustainable Energy 2011:30:S11-S23. doi:10.1080/1478646X.2010.542464

[10] Sachidanada S., Din M., Chandrika R., Sahoo G. P., Dam R. Performance Evaluation Of Biomass Fired Dryer For Copra Drying: A Comparison With Traditional Drying In Subtropical Climate. Journal of Food Processing Technology 2014:5:294. doi:10.4172/2157-7110.1000294

[11] Bala B. K., Morshed M. A., Rahman M. F. Solar drying of Mushroom using solar tunnel dryer. In: International solar food processing conference, Indore, India, 2009.

[12] Sujata N., Zeba N., Pushpendra Y., Ruchi C. Economic analysis of hybrid photovoltaic-thermal (PVT) integrated solar dryer. International journal of engineering inventions 2012:1(11):21-27.

[13] Selivanovs J., Blumberga D., Ziemele J., Blumberga A., Barisa A. Research of Woody Biomass Drying Process in Pellet Production. Environmental and Climate Technologies 2013:10:46-50.

[14] Coşar G., Pooyanfar M., Amirabedin E., Topal H. Design and Economic Analysis of a Heating/Absorption Cooling System Operating with Municipal Solid Waste Digester: A Case Study of Gazi University. Environmental and Climate Technologies 2013:11:12-18. doi:10.2478/rtuect-2013-0002

[15] Paturska A., Repele M., Bazbauers G. Economic Assessment of Biomethane Supply System based on Natural Gas Infrastructure. Energy Procedia 2015:72:71-78. doi:10.1016/j.egypro.2015.06.011

[16] Repele M., Bazbauers G. Life Cycle Assessment of Renewable Energy Alternatives for Replacement of Natural Gas in Building Material Industry. Energy Procedia 2015:72:127-134. doi:10.1016/j.egypro.2015.06.018

[17] Blumberga A., Blumberga D., Pubule J., Romagnoli F. Cost-Benefit Analysis of Plasma-based Technologies. Energy Procedia 2015:72:170-174. doi:10.1016/j.egypro.2015.06.024 
[18] Zvaigznitis K., Rochas C., Zogla G., Kamenders A. Energy Efficiency in Multi-Family Residential Buildings in Latvia. Cost Benefit Analysis Comparing Different Business Models. Energy Procedia 2015:72:245-249. doi:10.1016/j.egypro.2015.06.035
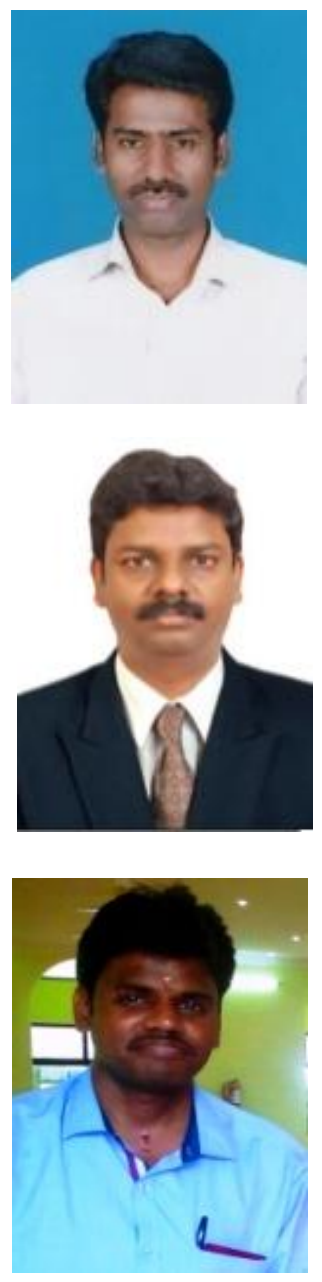

Dr. Vincent H Wilson obtained his B.E in Mechanical Engineering from GCT, Coimbatore and M.E in Refrigeration and Air conditioning from CIT Coimbatore. He obtained his $\mathrm{Ph}$. D from National Institute of Technology, Tiruchirapalli for his thesis entitled "Investigation of $\mathrm{NO}_{\mathrm{x}}$ emissions in a CI Engine through Optimization Techniques".

He has Twenty eight years of teaching experience in Engineering and Technology with a good exposure in Administration in Educational Institutions. Currently he is working as a Principal in Toc H Institute of Technology, Arakunnam, Kerala. He has published around 25 research papers both in referred national \& international journals and conferences proceedings. He has a various Membership in Professional Bodies few of those are Life Member, ISTE \& Executive Council member for ISTE -TN, Member, IUCEE (Indo US Collaboration for Engineering Education), Member, GEDC (Global Engineering Deans Council), Member, ASEE (American Society for Engineering Education), Member IFEES (International Federation for Engineering Education Societies) and Member Computer Society of India.

Dr. Kumarasamy Sudhakar obtained his B. E in Mechanical Engineering from Government College of Engineering, Salem, Madras University in 2001 and M. Tech in Energy Management from School of Energy \& Environment Studies, Devi Ahilya University, Indore in 2006. He obtained his Ph. D from National Institute of Technology, Tiruchirapalli for his thesis entitled "Technical and Economic Feasibility of $\mathrm{CO}_{2}$ Sequestration using microalgae in India in 2013. His major research areas include Climate Change, Carbon Sequestration, Biofuel, Solar Thermal and PV Systems, Sustainability assessment, Hybrid Energy systems; Mathematical Modelling, Exergy analysis and Energy Conservation. He has received MHRD GATE and DST Senior research fellowship from Government of India for his Doctoral Research

He worked in National Institute of Technology, Tiruchirapalli from 2008-2010. He has been actively involved in teaching \& research in the area of Energy \& Environment. He has published around 70 research papers both in referred National \& International journals and conferences proceedings. He has authored more than 10 technical books. He is a certified Energy Manager \& Auditor by BEE, Ministry of Power, Govt of India. He has a various meritorious awards to his credit. 